Review Article

\title{
PLANT PROFILE, PHYTOCHEMISTRY AND PHARMACOLOGY OF SPATHODEA CAMPANULATA P. BEAUVAIS (AFRICAN TULIP TREE): A REVIEW
}

\author{
ANITA S. WAGH*, SANTOSH R. BUTLE \\ Department of Pharmacognosy, School of Pharmacy, S. R. T. M. University, Nanded 431606, Maharashtra, India \\ Email: anita_sw@rediffmail.com
}

Received: 03 Dec 2017 Revised and Accepted: 22 Mar 2018

\begin{abstract}
Plants have been used as one of the important source for treating various diseases of human beings since ancient times. Numbers of plants are mentioned in different traditional system of medicine, among them Spathodea campanulata P. Beauvais is one of the important medicinal plant. Different parts of Spathodea campanulata such as flowers, leaves, stem, bark and roots have been reported for possessing anti-inflammatory, analgesic, cytotoxic, anti-diabetic and anticonvulsant activity. Phytochemical screening shows the presence of various secondary metabolites like alkaloids, tannins, flavonoids, glycosides and sterols. Relevant information and literature on Spathodea campanulata from electronic databases such as Academic Journals, Google, Google Scholar, Science Direct, PubMed and Web of Science were collected and analyzed. Available literatures evidently show that Spathodea campanulata possess a wide range of pharmacological activities that could be explained by the presence of variety of phytochemicals. The aim of the present review to provide detailed information regarding geographical distribution, phytochemicals and pharmacological properties of this plant.
\end{abstract}

Keywords: Spathodea campanulata P. Beauvais, Phytochemicals, Flavonoids, Pharmacology

(C) 2018 The Authors. Published by Innovare Academic Sciences Pvt Ltd. This is an open access article under the CC BY license (http://creativecommons.org/licenses/by/4.0/] DOI: http://dx.doi.org/10.22159/ijpps.2018v10i5.24096

\section{INTRODUCTION}

Medicinal plants play an important role in our natural wealth. They serve as an important therapeutic agent as well as valuable raw material for manufacturing numerous traditional medicines and also acts as the lead for modern medicines. The history of medicinal plants uses for treating disease and ailments is probably dated back to human civilization. World Health Organization (WHO) estimated that about three-quarters of the world's population currently uses herbs or other forms of traditional medicines to treat illness. Even in the USA, the use of plants and phytomedicines has increased dramatically [1]. The large diversity of medicinal plant species is a huge source of potentially active phytochemicals with novel structures. Approximately 119 pure chemical substances isolated from higher plants are used in medicine throughout the world [2] Spathodea campanulata P. Beauvais is one of the medicinally important perennial plants commonly used as folkloric medicine in Nigeria. The species Spathodea campanulata belong to the family Bignoniaceae and is native to Africa. It is often used in gardening in tropical and subtropical areas, including South America [3]. The flowers are used as diuretic and anti-inflammatory, while the leaves are against kidney diseases, urethra inflammations and as an antidote against animal poisons [4]. Several phytochemical studies were performed with different parts of Spathodea campanulata including stem barks, leaves, flowers and fruits. The leaves contain spathodol, caffeic acid, other phenolic acids and flavonoids, while fruits contain polyphenols, tannins, saponins and glycosides [5]. The plant leaves reported to have antiplasmodial, analgesic, antiinflammatory and anti-larvicidal activity. The stem bark decoction of Spathodea campanulata have been displayed hypoglycemic, anticomplementary, antimalarial and anti-HIV activity [6].

\section{Geographical distribution}

Spathodea campanulata P. Beauvais tree is native to Africa. In tropical Africa it is planted as an ornamental plant, e. g. in Cape Verde, Zimbabwe and Madagascar. It is widely grown in tropical and subtropical regions outside Africa [7]. This plant is also commonly found in India as an ornamental plant.

\section{Scientific classification, local and vernacular names}

This plant is also called as African tulip tree or Flame tree, Spathodea campanulata $\mathrm{P}$. beauv is the botanical name. It is a single species of the monotypic genus Spathodea in the flowering plant family Bignoniaceae which is composed of around 800 species distributed in 112 genera [8].

Table 1: Scientific classification, local and vernacular names

\begin{tabular}{lll}
\hline Scientific classification & Vernacular names & Local names \\
\hline Kingdom: Plantae & English: African tulip tree, & Hindi: Rugtoora \\
Order: Lamiales & Cantonese: Neerukayi mara & Marathi: Pichakari \\
Family: Bignoniaceae & French: immortel éntranger & Malay: Panchut-Panchut \\
Tribe: Tecomeae & Spanish: Tulipán Africans, & Tamil: Patadi \\
Genus: Spathodea & in Puerto Rico meaíto. & English: flame of the forest,tulip tree \\
Species: S. campanulata P. Beauv. & Sinhala: Kudulu & Kannada: Neerukayi mara \\
& Luganda: Kifabakazi & Malayalam: Poomaram \\
\hline
\end{tabular}

\section{Morphology of Spathodea campanulata P. Beauvais}

Spathodea campanulata P. Beauvais is a large upright tree with a spreading crown (fig. 1a) and a slightly buttressed trunk (fig. 1b). The branches are thick and marked with small whitish-coloured corky spots. Younger branches vary from being almost hairless to having a sparse covering of small hairs (fig. 1c). The large leaves are up to 50 $\mathrm{cm}$ long, compound with 7-17 leaflets. These leaves are usually oppositely arranged along the stems (fig. 1d). The large, orange-red flowers are arranged in dense clusters $(8-10 \mathrm{~cm}$ long) at the tips of the 
branches. The reddish-orange coloured petals are also fused together and are shaped somewhat like a tulip flower i.e. tubular ((fig. 1e). Flowering occurs throughout the year, but usually peaks during

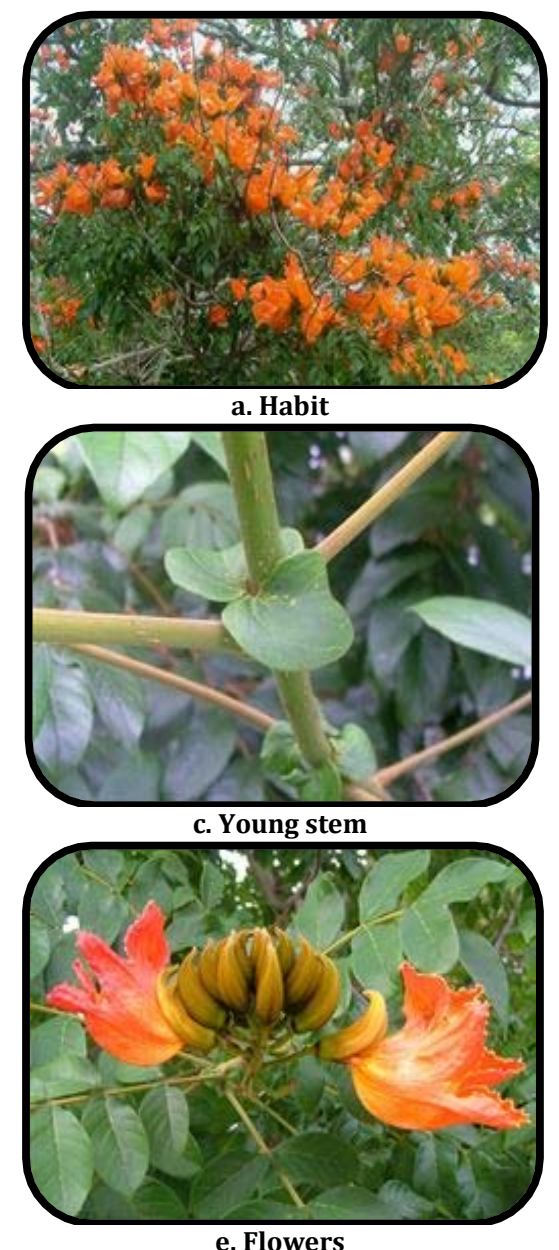

spring. The fruits are long, elongated capsules resemble pods ((fig. 1f). When mature they split open and release about 500 papery seeds. These seeds are very light and surrounded by membranous wing [9].

Fig. 1: Different parts of Spathodea campanulata P. beauv [10]

\section{Traditional uses}

Spathodea campanulata is traditionally used in the treatment of various disorders. The bark pulp is used in oedemas, skin diseases like herpes and sores. In Gabon, the crushed bark and flowers have been applied to ulcers. The cold leaf infusion is used to treat urethral inflammation and bark decoction has been reported to be used to treat kidney disorders [11]. In Senegal, the bruised leaves and flowers are used in wound treatment and ulcers. The flowers are employed as diuretic and anti-inflammatory, while the leaves are used against kidney disease, urethra inflammation and as an antidote against animal poisons. Also, the leaf decoction has been

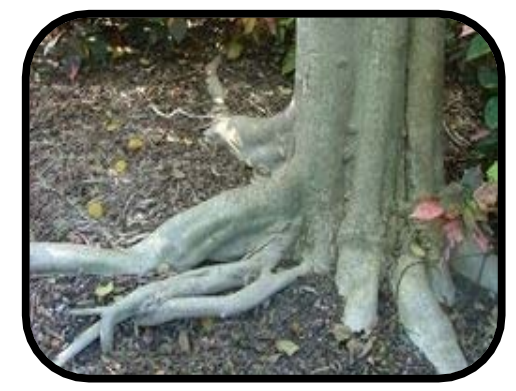

b. Trunk

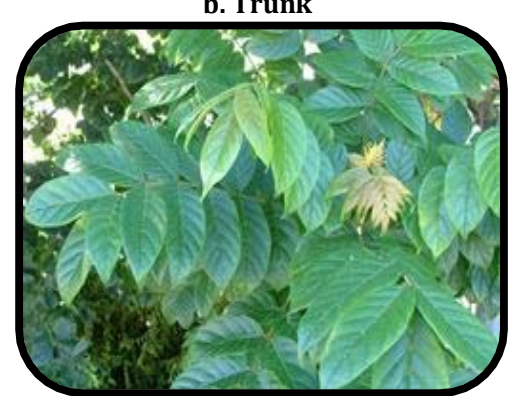

d. Leaves

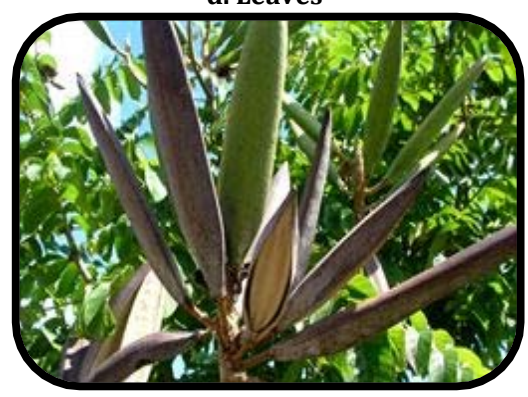

f. Fruits

Table 2: Phytochemicals isolated from different parts of the plant

\begin{tabular}{|c|c|}
\hline Parts of the plant & Isolated phytochemicals \\
\hline \multirow[t]{4}{*}{ Stem bark } & Triterpenes and Sterols \\
\hline & N-alcohols (35\%), octacosanol and triacontanol [14]. \\
\hline & $\begin{array}{l}\text { Spathoside, n-alkanes, linear aliphatic alcohols, sitosterol and their esters, beta-sitosterol-3-0-beta-D-glucopyranoside, } \\
\text { oleanolic acid, pomolic acid, p-hydroxybenzoic acid and phenylethanol ester [15]. }\end{array}$ \\
\hline & 13ß-acetoxyoleanolic acid, siaresinolic acid, $3 \beta$-acetoxy-12-hydroxyoleanan-28, 13-olide and oleanolic acid [16]. \\
\hline \multirow[t]{2}{*}{ Leaves } & Spathosides A, B and C, Verminoside, 6'-O-trans-caffeoyl-loganic acid, Catalpol and Ajugol [17]. \\
\hline & Spathodol, Caffeic acid, Phenolic acid and Flavonoids [18]. \\
\hline Root peels & Methyl $p$-hydroxybenzoate and $p$-hydroxybenzoic acid [19]. \\
\hline Fruits & Polyphenols, Tannins, Saponins and Glucosides [19]. \\
\hline \multirow[t]{3}{*}{ Flowers } & 1,1-diethoxy-3-methyl-butane, \\
\hline & N-hexadecanoic acid, 1,2-benzenedicarboxylic acid diisooctyl ester, and oleic acid [20]. \\
\hline & $\begin{array}{l}\text { Phytol, } \alpha \text {-methyl Cinnamaldehyde, } \beta \text {-sitosterol-3-acetate, naringenin, catechin-3-0- } \alpha \text {-rhamnopyranoside and 5, 6, 4' } \\
\text { trihydroxy flavonol-7-0- } \alpha \text {-rhamnopyranoside. Anthocyanins } 21]\end{array}$ \\
\hline
\end{tabular}


Table 3: Chemical structure of isolated phytochemicals from different parts of the plant

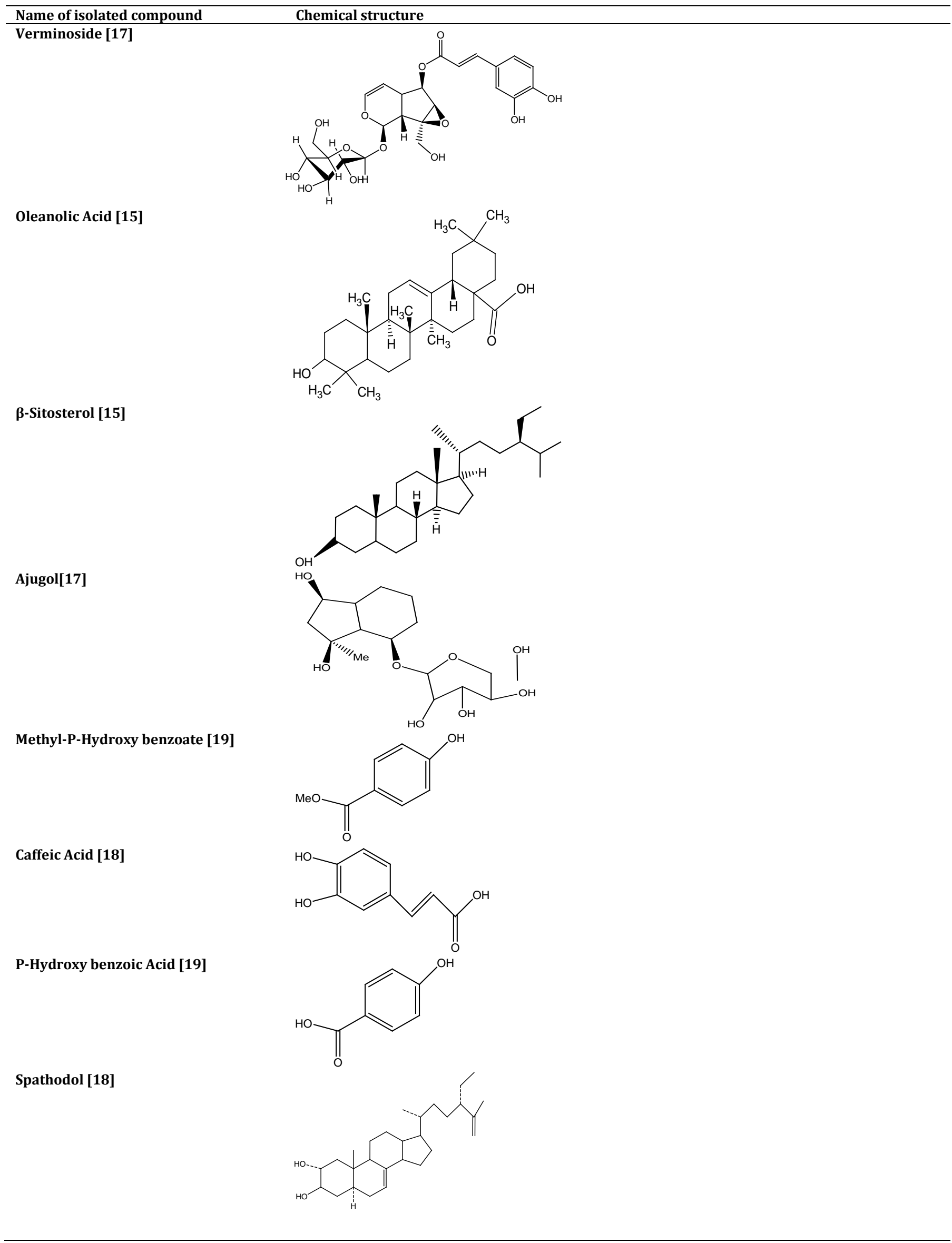




\section{Pharmacological activities}

\section{Molluscicidal activity}

Mendes et al., investigated molluscicidal activity of hexane and ethyl acetate extract of flowers and stem bark of Spathodea campanulata P. beauv against adults and egg masses of Biomphalaria glabrata [13].

\section{Hypoglycemic, anti-complement and Anti-HIV activities}

Niyonzima et al., evaluated hypoglycemic, anti-complement and antiHIV activities of stem bark decoction of Spathodea campanulata P. beauv. The decoction was separated into different fractions by column chromatography by using different non-polar to polar solvents and fractions were evaluated for hypoglycemic activity in mice. The most polar fraction showed a prominent hypoglycemic activity in mice. Spathodea campanulata stem bark fractions also showed anti-HIV and anti-complement activities. Anti-HIV activity was evaluated on MT-4 cell lines using MTT assay [6].

\section{Analgesic and anti-inflammatory activity}

Emmanuel and Peter investigated analgesic and anti-inflammatory activity of Spathodea campanulata P. beauv using cold, thermal and chemical-induced pain models and carrageenan-induced acute inflammation in rats. The leaves of the Spathodea campanulata were extracted using ethanol (70\%) by cold maceration and defatted with Petroleum ether $\left(40-60^{\circ}\right)$. The results showed that the extract (250$1000 \mathrm{mg} / \mathrm{kg})$ significantly $(\mathrm{P}<0.05)$ and dose-dependently prolonged the pain reaction times in hot-plate and tail flick pain models and reduced acetic acid induced writhing. The ethanolic extract showed significant anti-inflammatory activity against acute inflammation induced by carrageenan. [22].

\section{Antioxidant activity}

Heim et al., studied antioxidant activity of flower and bark extract of Spathodea campanulata P. beauv by lipid peroxidation mechanism. Ethanol extracts of bark and flowers showed antioxidant activity on lipid peroxidation of liver microsome induced by $\mathrm{Fe}^{3+}$-ascorbic acid. Bark extracts were 5 times more efficient than flower extract. Antioxidant activity of flower extract previously complexed with increasing concentrations of $\mathrm{Fe}^{3+}(20-100 \mu \mathrm{m})$ which resulted in the antioxidant activity loss, was shown to be related to iron complex formation. In contrast, the antioxidant activity of bark extract was not inhibited by the previous $\mathrm{Fe}^{3+}$ complexation which was demonstrated by spectral analysis. These results suggest that the antioxidant mechanisms of Spathodea campanulata P. beauv flower and bark extracts are different from each other [23].

\section{Anticonvulsant activity}

Emmanuel et al. evaluated the anticonvulsant activity of a glycoside isolated from the leaf of Spathodea campanulata P. beauv. The ethanol leaf extract was subjected to bioactivity guided fractionation and isolation of the active compound. The Anticonvulsant effect of the isolated compound was determined using pentylenetetrazole and electrically induced seizures. Activities related to anticonvulsion such as the effect on rotarod performance and phenobarbitone induced-sleeping time was investigated. Also the acute toxicity studies, as well as the structural elucidation of the isolated compound were carried out using Nuclear Magnetic Resonance and mass spectrometry. Results indicated that the new active compound isolated from Spathodea campanulata exhibited significant $\quad(p<0.05)$ abolition of seizures induced by pentylenetetrazole and maximal electroshock seizures. Acute toxicity studies of the isolated compound estimated an oral and intraperitonial $\mathrm{LD}_{50}$ of 323.59 and $158 \mathrm{mg} / \mathrm{kg}$ respectively. Structure of the isolated glycoside was found to be urs-12-en-27 $\alpha, 30$ di-oic acid 3-0- $\alpha$-L-rhamnopyranosyl $(1 \rightarrow 2) \alpha$-L-arabinopyranoside [24].

\section{Hepatoprotective activity}

Charles et al., evaluated hepatoprotective and curative potential of the aqueous extract of the stem bark of Spathodea Campanulata P. beauv in a carbon tetrachloride-induced model of hepatotoxicity in rats. In both the prophylactic and curative studies, significant hepatoprotective effects were obtained against liver damage induced by carbon tetrachloride in experimental rats. These results correlated with the histopathology of liver for treated and control groups as well as the antioxidant protective capacity. The hepatoprotective activity of the extract is linked to its antioxidant capacity and inhibition of CYP 450 enzymes, possibly interfered with $\mathrm{CCl}_{4}$ bioactivation and thus protected the hepatocytes. The present study thus showed that the aqueous stem bark extract of Spathodea campanulata significantly protects reverse $\mathrm{CCl}_{4}$ hepatic damage in rats [25].

\section{Antimicrobial activity}

Ofori-Kwakye et al. studied antimicrobial activity of different extracts of the stem bark of Spathodea campanulata P. beauv against B. subtilis, E. coli, P. aeruginosa and $S$. aureus. The minimum inhibitory concentration of the methanol extract was determined against the four bacteria strains i.e. B. subtilis, E. coli, P. aeruginosa, $S$. aureus and $C$. albicans using the broth dilution method. The coarsely milled stem bark of Spathodea campanulata P. beauv was extracted by soxhlet apparatus separately using water, ethanol $(96 \% \mathrm{w} / \mathrm{v})$, methanol and petroleum ether as solvent. The methanol and ethanol extracts exhibited high activity while the aqueous and petroleum ether extracts showed little activity against the test organisms. The minimum inhibitory concentration of the methanol extract of Spathodea campanulata P. beauv was found to be C. albicans (45-50 $\mathrm{mg} / \mathrm{ml})$, B. subtilis and E. coli $(50-55 \mathrm{mg} / \mathrm{ml})$, P. aeruginosa $(60-65$ $\mathrm{mg} / \mathrm{ml})$, S. aureus $(145-150 \mathrm{mg} / \mathrm{ml})$. For the methanol extract, antimicrobial activity was in the order as E. coli $>B$. subtilis $>P$. aeruginosa $>S$. aureus. For the ethanol extract, antibacterial activity followed the order: B. subtilis $>$ E. coli $>$ P. aeruginosa $>$ S. aureus. On the whole, the methanol extract of the stem bark of Spathodea campanulata P. beauv showed the highest antibacterial activity against the test organisms [26].

\section{Antimalarial activity}

Makinde et al., investigated the antimalarial activity of the extracts of the stem bark of Spathodea campanulata P. beauv on Plasmodium berghei in mice. Sun-dried stem bark material was extracted with hexane, methanol, chloroform and water. The blood schizontocidal activity of the extracts was studied in early and established infections using chloroquine as the reference drug against Plasmodium berghei. The prophylactic action of the extracts was also investigated with standard drug pyrimethamine. Both the hexane and chloroform extracts demonstrated significant activities in the 4-Day test and Rane test. The chloroform extract demonstrated some prophylactic properties. Whereas the result obtained with aqueous extracts was not significantly different from the control used in the test. Therefore the aqueous extract did not show any significant antimalarial property [27].

\section{Cytotoxicity activity}

Victor et al. investigated the cytotoxic activity of the methanolic extract of Spathodea campanulata P. beauv. Methanolic extract was obtained by soaking the air-dried material in methanol for $48 \mathrm{~h}$ at room temperature activity and studied for cytotoxic activity by Resazurin Reduction assay against sensitive leukemia CCRF-CRM cell lines. The methanolic extract displayed IC 50 value below $80 \mu \mathrm{g} / \mathrm{ml}[28]$.

\section{Anti-cataract activity}

Adio et al. evaluated the anti-cataract activity of fresh flower bud exudates of Spathodea campanulata P. beauv against cataract genesis using rat lenses. Cataractogenesis was evaluated through the determination of the levels of anti-oxidant parameters such as total protein, glutathione, malondialdehyde and activities of superoxide dismutase and catalase was evaluated in the lens homogenates. Exudates significantly decreases the levels of glutathione and total protein, reduction in superoxide dismutase and Catalase activities as well as an increase in malondialdehyde content were observed in cataractous lenses when compared with the normal control. Flower bud exudates of Spathodea campanulata P. beauv displayed a dose related anti-cataract activity [29].

\section{Antifungal activity}

Driana et al., isolate Iridoid glycoside (ajugol) and two phenolic derivatives ( $p$-hydroxybenzoic acid and methyl $p$-hydroxybenzoate) 
from the ethanolic extract of Spathodea campanulata P. beauv (Bignoniaceae) roots peels. These isolated compounds evaluated against fungus Cladosporium herbarum. The Iridoid glycoside (ajugol) did not exhibit any antifungal activity against Cladosporium herbarum, while phenolic constituents ( $p$-hydroxybenzoic acid and methyl $p$-hydroxybenzoate) displayed antifungal activity [30].

\section{Antidiabetic activity}

Tanayen et al. investigated the antidiabetic activity of methanolic stem bark extract of Spathodea campanulata $P$. beauv. The methanolic extract was subjected to serial solvent fractionation with hexane, ethyl acetate and chloroform and evaluated for antidiabetic activity using a modification of the oral Glucose tolerance test. The activity result indicated that the various fractions reduced glucoseinduced hyperglycemia though there was no statistically significant reduction $(\mathrm{p}<0.05)$. Considering the percentage reduction of hyperglycemia, the control had a reduction of $44.7 \%$. The hexane fraction had a dose-dependent reduction $44.4 \%$ at $50 \mathrm{mg} / \mathrm{kg}, 48.2 \%$ at $100 \mathrm{mg} / \mathrm{kg}$ and $49 \%$ at $200 \mathrm{mg} / \mathrm{kg}$. The ethyl acetate fraction reduced hyperglycemia by $48.5 \%$ at $50 \mathrm{mg} / \mathrm{kg}, 46.5 \%$ at $100 \mathrm{mg} / \mathrm{kg}$ and $42.3 \%$ at $200 \mathrm{mg} / \mathrm{kg}$. The residual aqueous fraction reduced hyperglycemia by $67.3 \%$ at $50 \mathrm{mg} / \mathrm{kg}, 53.4 \%$ at $100 \mathrm{mg} / \mathrm{kg}$ and $74.7 \%$ at $200 \mathrm{mg} / \mathrm{kg}$. Metformin the standard euglycemic agent reduced the hyperglycemia by $48 \%$ at the dose of $500 \mathrm{mg} / \mathrm{kg}$. All the three fractions tested possess antihyperglycemic activity and the hexane fraction exhibiting a clearer dose-dependent activity [31].

\section{Anti-solar activity}

Patil VV et al. evaluated the UV absorption ability of flowers of Spathodea campanulata as an anti-solar agent. The flower petals were extracted with distilled water: methanol $(2: 5)$ by maceration. The UV absorption spectrum for the extract was taken in the range of 200-400 nm using double beam UV-visible spectrophotometer. The extract showed a prominent absorbance at 200-240 nm, while good absorbance at a range of $240-325 \mathrm{~nm}$. The moderate absorbance was noted at the range of 310-340. The result obtained were showed the ability of extract to absorb UV radiation and proved its UV protection ability hence can be used as an anti-solar agent [32].

\section{Acute and subchronic toxicities study}

Ilodigwe et al., evaluated the acute and subchronic toxicities of the ethanol leaf extract of Spathodea campanulata P. beauv as an anticonvulsant drug. For the acute toxicity study, $1000-5000 \mathrm{mg} / \mathrm{kg}$ of the ethanol leaf extract were administered to rats and toxic symptoms and mortality $24 \mathrm{~h}$ post administration of the extract were determined. The median lethal dose $\left(\mathrm{LD}_{50}\right)$ of the extract was determined. In the subchronic study, $750-3000 \mathrm{mg} / \mathrm{kg}$ of the extract were administered daily for $90 \mathrm{~d}$. The food and water consumption, body weight changes, as well as haematological and biochemical parameters, were determined periodically. The estimated $\mathrm{LD}_{50}$ of the extract was $4466.84 \mathrm{mg} / \mathrm{kg}$. There was no mortality during the period of study but the animals showed signs of anorexia, weakness, sluggishness and significant $(\mathrm{p}<0.05)$ reduction in food and water intake and body weight. The effects on haemoglobin concentration, Packed Cell Volume, red blood cell and white blood cell counts were non-significant $(P>0.05)$. The extract caused significantly $(\mathrm{p}<0.05)$ increases in serum liver enzymes, Aspartate Aminotransferase, Alkaline Phosphatase and Alanine Aminotransferase. These changes showed recovery after $28 \mathrm{~d}$ post-treatment. These results suggested that the leaf extract of $S$. campanulata is safe in the treatment of epilepsy [33].

\section{Search criteria}

- Electronic databases-Academic Journals, Google,Google Scholar, PubMed, Web Science, Science Direct, data sheets, Record from PROTA4U.

- Key Words-Spathodea campanulata, Traditional Use, Phytochemicals, Pharmacology.

- Software-Chemdraw, Chemsketch, Ginger, Grammar checker.

\section{CONCLUSION}

From the review of the existing work, it was concluded that Spathodea campanulata P. Beauvais has been used in the treatment of various diseases and reported to have antimalarial, anticancer, antidiabetic, antioxidant and antibacterial activities. In the recent year's traditional medicines received more attention and evaluated for its efficacy and generally, they are safe for human beings. Numerous phytochemical and pharmacological studies have been conducted on different parts of the Spathodea campanulata P. Beauvais. Further investigation to explore the therapeutic action of the individual phytochemicals and their mechanism of action can be encouraged.

\section{ACKNOWLEDGEMENT}

Authors are thankful to the Director, School of Pharmacy, S R T M University, Nanded for providing necessary facilities.

\section{AUTHOR CONTRIBUTION}

Both the authors had contributed equally to the review work.

\section{CONFLICT OF INTERESTS}

We declare that we have no conflict of interest.

\section{REFERENCES}

1. Parul T, Aditi S. Natural resources from plants in the treatment of cancer: an update. Asian J Pharm Clin Res 2017;10:13-22.

2. Farnsworth NR, Akerele O, Bingel AS, Soejarto DD, Goo ZG. Medicinal plants in therapy. Bull WHO 1985;63:965-81.

3. Joly AB. Introduction to taxonomic vegetation. $7^{\text {th }}$ ed. Sao Paulo: Ed. National; 1985.

4. Mensah AY, Houghton PJ, Dickson RA, Fleischer TC, Heinrich M, Bremner P. In vitro evaluation of effects of two Ghanaian plants relevant to wound healing. Phytother Res 2006;20:941-4.

5. Ngouela S, Tsamo E, Sondengam BL. Extractives from bignoniaceae: constituents of the stem bark of Spathodea campanulata. Planta Med 1988;54:476.

6. Niyonzima G, Laekernan G, Witvrouw M, Van Poel B, Pieters L. Hypoglycemic, anti-complement and anti-HIV activities of Spathodea campanulata stem bark. Phytomedicine 1999; 6:45-9.

7. Bosch CH. Spathodea campanulata P. Beauv. [Internet] Record from PROTA4U. Oyen, L. P. A. and Lemmens, R. H. M. J. (Editors); 2002.

8. Spangler RE, Olmstead RG. Phylogenetic analysis of bignoniaceae based on the cp DNA gene sequences rbcL and ndhF. Ann Mo Bot Gard 1999;86:33-46.

9. Orwa C, Mutua A. Agroforestre database: a tree reference and selection guide version; 2009.

10. Identic Pty Ltd. Special edition of Environmental Weeds of Australia for Biosecurity Queensland; 2016.

11. Abbiw DK. Useful plants of Ghana. Intermediate Technology publications Ltd: London, UK; 1990.

12. Mendes NM, De Souza CP, Araujo N, Pereira JP, Katz N. Molluscicidal activity of some natural products on biomphalaria glabrata. Mem Inst Oswaldo Cruz 1986;81:87-91.

13. Brindha P, Nagarajan A, Saralla RP, R Narendran R, Sridharan K. A study on chemical and botanical standards of a traditional drug source Spathodea campanulata beauv. Int J Pharm Pharm Sci 2012;4:157-60.

14. Gormann R, Schreiber L, Kolodziej H. Cuticular wax profiles of leaves of some traditionally used African Bignoniaceae. Z Naturforsch C 2004;59:631-5.

15. Mbosso EJ, Ngouela S, Nguedia JC, Penlap V, Rohmer M, Tsamo E. Spathoside, a cerebroside and other antibacterial constituents of the stem bark of Spathodea campanulata. Nat Prod Res 2008;59:296-304.

16. Silvere N, Etienne T, Beibam L. Sondengam. Extractives from bignoniaceae: constituents of the stem bark of Spathodea campanulata. Planta Med 1988;54:476

17. Gouda YG. Iridoids from Spathodea campanulata P. Beauvais leaves. Nat Prod Commun 2009;4:753-6. 
18. El-Hela A. Phenolics from Spathodea campanulata Beauv leaves. Afr J Plant Sci 2001;27:152-62.

19. Amusan 00, Adesogan K, Makinde JM. Antimalarial active principles of Spathodea Campanulata stem bark. Phytother Res 1996;10:692-3.

20. Kumaresan M, Palanisamy PN, Kumar PE. Chemical investigation of the flower of Spathodea campanulata by GCMS. J Nat Prod Plant Resour 2011;1:14-7.

21. Naglaa GS, Hanaa HE, Soheir M. Bioactivity and composition of the flowers of Spathodea campanulata p. Beauv World J Pharm Res 2014;3:213-30.

22. Emmanuel EI, Peter AA. Spathodea Campanulata: an experimental evaluation of the analgesic and anti-inflammatory properties of a traditional remedy. Asian J Med Sci 2009;1:35-8.

23. Heim SC, Guarnier FA, Ferreira DT, Braz-Filho R, Cecchini R, Cecchini AL. Antioxidant activity of Spathodea campanulata (Bignoniaceae) extracts. Rev Bras Plant Med 2012;14:287-92.

24. Emmanuel EI, Peter AA, Theophine CO, Edwin 00. Anticonvulsant effects of a glycoside isolated from the leaf of Spathodea campanulata P. Beauv. J Med Plants Res 2010; 20:1895-900.

25. Charles A, Phyllis ED, Emmanuel A. Aqueous stem bark extract of Spathodea campanulata (P. Beauv) modulates carbon tetrachloride induced hepatic damage in rats. AJPT 2013;8:39-50.

26. Ofori-Kwakye K, Kwapong AA, Adu F. Antimicrobial activity of extracts and topical products of the stem bark of Spathodea campanulata for wound healing. Afr J Trad CAM 2009;6:16874.

27. Makinde JM, Amusan 00, Adesogan EK. The antimalarial activity of Spathodea campanulata stems bark extract on Plasmodium berghei in mice. Planta Med 1988;54:122-5.

28. Victor K, Cedric T, Flora TM, Veronique PB, Thomas E. Cytotoxicity of methanolic extracts of 10 Cameroonian medicinal plants towards multi-factorial drug-resistant cancer cell lines. BMC Complementary Altern Med 2016;16:1-18.

29. Adio GI, Faluyi JO, Osoniyi O. Evaluation of the effect of Spathodea campanulata flower bud exudates on Cataractogenesis in rat lenses. Afr J Tradit Complement Altern Med 2014;11:83-91.

30. Driana P, Jurandir PP, Dalva TF, Noemia KI, Raimundo B. Iridoid glucoside and antifungal phenolic compounds from Spathodea campanulata roots. Semina: Ciências Agrárias, Londrina 2007;28:251-6.

31. Tanayen JK. Phytochemical and antidiabetic evaluation of the methanolic stem bark extract of Spathodea campanulata (P. Beauv.) bignoniaceae. Pharmacogn J 2016;8:243-8.

32. Patil VV, Patil SB, Kondawar MS, Naikwade NS, Magdum CS. Study of methanolic extract of the flower of Spathodea campanulata L. as an anti-solar. Int J Green Pharm 2008;3:248-9.

33. Ilodigwe EE, Akah PA, Nworu CS. Evaluation of the Acute and Subchronic Toxicities of ethanol leaf extract of Spathodea campanulata P. Beauv. IJAR Nat Prod 2010;3:17-21. 